\title{
Growing the pie or slicing it differently - on the need to disentangle two aspects of trade agreements
}

\begin{abstract}
Recent trade negotiations frequently include investor protection clauses. The currently stalled TTIP negotiations are but one example for this trend. Against the background of an analysis of the case for trade, the paper asks whether such clauses can be justified from a normative perspective. More specifically, what is the impact of investor protection on the domestic distribution of the gains from trade between labour and capital, and how should we assess this impact from the perspective of justice? In order to answer this question, the paper develops a series of ideal-type scenarios that reflect the consequences of investor protection on employment on the one hand, and on the distributive conflict between labour and capital on the other. While no claim is made which of these scenarios corresponds to TTIP or other trade agreements, they provide a useful normative framework to analyse such agreements.

Keywords: Trade; justice; distribution; investor protection; TTIP
\end{abstract}

Conventional wisdom in economics states that free trade promotes economic growth and thus raises standards of living. However, at this level of generality, this statement is simplistic. What exactly is meant by 'free' trade? Does it always promote economic growth, and does economic growth always promote standards of living? Moreover, whose standards of living? Is the rise in the quality of life equally or fairly distributed between individuals? Do the answers to these questions vary depending on the relative standing and power of the two parties in the trade relationship, that is, does it matter whether there is a level-playing field between them? What exactly do we mean by a level-playing field in international economics? A comprehensive assessment of the pros and cons of international trade agreements requires answers to these questions. The fact that such answers are not easy to come by in part explains why trade agreements tend to be controversial.

A new trend in trade negotiations is the inclusion of investor protection clauses. From the perspective of foreign investors, the advantages of such clauses are obvious: They provide a stability of the regulatory environment that goes far beyond that of standard market democracies. For example, they might guarantee investors no changes in environmental or labour standards or, if such changes do occur, compensation for the resulting cost differential. From the perspective of the states offering such clauses, the hope is to attract more foreign direct investment (FDI) and thus to stimulate growth. Even if this strategy 
is individually effective, which is an empirical issue that is controversial, the allocation of investment between countries at least to some extent represents a zero-sum game, which undermines the case for such clauses from a collective viewpoint. Finally, from the perspective of other constituencies, such as labour or environmental interests, investor protection clauses are likely to be counterproductive. Hence, whatever the overall assessment of such clauses, they are bound to raise issues of distributive justice.

The now stalled Transatlantic Trade and Investment Partnership (TTIP) between the European Union and the United States represents both an example for a trade treaty draft that includes investor protection clauses and a good illustration of the surrounding controversies. While the outcome of the 2016 US presidential election has made it less likely that TTIP will actually see the light of day, subjecting its proposed content to normative scrutiny is still a worthwhile exercise. The Canada-European Union Comprehensive Economic and Trade Agreement (CETA) offers another case study. It was signed in October 2016, even though parts - including clauses on investor protection - remain suspended due to a lack of consensus. New trade agreements will be signed in the future, and it is a good idea to reflect on what kind of clauses they should and should not contain.

This paper aims to distinguish two facets of trade agreements: the gains from trade through increased specialisation on the one hand from a different distribution of the gains from trade on the other. Even if the line between the two cannot always be drawn with precision, the distinction is important and often neglected by policy analysis. In particular, the paper mobilizes this distinction to assess investor protection clauses.

The argument is structured as follows. Section 1 develops a taxonomy of questions of fairness in the context of trade. Against this background and using TTIP as illustration, section 2 introduces the distinction at the heart of the paper, namely that between the aggregate versus the distributive effects of investor protection clauses. Finally, section 3 introduces a number of stylised trade scenarios to allow us to sharpen the distinction between genuine gains from trade on the one hand and a mere redistribution of these gains on the other.

\section{Justice in trade}

In order to isolate the aspect of justice in trade this paper focuses on, it is useful to reconstruct the economic case for trade as it has been made in the history of economic thought. Notably, doing so shows that the distinction between the economic benefits of trade in terms of growth on the one hand and the distribution of these benefits has always been central to trade theory. 


\section{The case for trade}

In a first step, consider David Ricardo's theory of trade. ${ }^{1}$ It shows that trade is advantageous, even for countries that hold an absolute advantage in all goods and services over their trading partners, that is, even for countries that are more productive across the board than others. Countries should specialize in the production of the good or service for which they have a comparative advantage, that is the good for which their opportunity cost in terms of other goods is lower. If A can produce either one car or four computers and B can produce either one car or five computers, A's opportunity cost of producing one car is lower and A should thus specialise in cars and B in computers. Ricardo's argument was developed further by the Heckscher-Ohlin model of international trade, which introduced differential capital endowments of trading partners. ${ }^{2}$ According to this model, countries will export goods that rely heavily on their abundant factors of production and will import goods that rely heavily on their scarce factors of production.

Three claims are often associated with this basic case for trade, and all three need to be put into perspective. First, it is argued that trade is always beneficial, in the sense that it will not just raise aggregate production, but that it will do so in all countries concerned when looked at in isolation. Teson puts forward a contemporary version of this argument. ${ }^{3}$ In fact, he goes even further by arguing that since the gains from specialisation and trade increase production, liberalising trade in order to realise these gains is required by justice because it represents a Pareto improvement. One objection to this line of argument is empirical. As John Stuart Mill claimed early on, ${ }^{4}$ there are circumstances in which imposing a tariff - and thus restricting trade - can be beneficial for a country by improving its terms of trade ${ }^{5}$ in the long term. It is an empirical question how common such cases are, and thus how much of a threat they pose to the general case for trade.

Second, it is worth noting that the standard economic textbook case for trade is made exclusively by appealing to the gains from cooperation: in the basic model, both countries stand to gain from trade, and they thus have an interest

1 David Ricardo, On the Principles of Political Economy and Taxation, 3rd edition (London: John Murray, 1821). $<$ http://www.econlib.org/library/Ricardo/ricP.html> (Accessed: 17 November 2017).

2 Eli Filip Heckscher, Bertil Gotthard Ohlin, Henry Flam and M June Flanders, Heckscher-Ohlin trade theory, translated, edited and introduced by Henry Flam and M June Flanders (Cambridge, MA; London: MIT Press, 1991).

3 Fernando Teson, 'Why Free Trade is Required by Justice', Social Philosophy and Policy 29/1 (2012), 126-153.

4 See John Stuart Mill, Principles of Political Economy with Some of Their Applications to Social Philosophy, in J. M. Robson (ed.), Collected Works of John Stuart Mill, vols. 2 and 3 (Toronto: University of Toronto Press, 1965), pp. 918-19.

5 The terms of trade are a measure of the bargaining power a country has in a trade relationship with other countries. They determine how much of the gains from specialisation go to each trading partner. The terms of trade will be in one's favour, for example, if one happens to be well endowed with a scarce resource. 


\section{GROWING THE PIE OR SLICING IT DIFFERENTLY - ON THE NEED \\ TO DISENTANGLE TWO ASPECTS OF TRADE AGREEMENTS}

to cooperate. Framing trade in this way is taken on board by many normative evaluations of trading practices, too. Aaron James for instance analyses trade in terms of an assurance game, where countries are faced with a basic uncertainty about whether their trading partners will stick to their side of the bargain. ${ }^{6}$ To give a concrete albeit simplified example, suppose the UK and France specialise according to their comparative advantage and trade French cheese for British shirts. Since under this arrangement the French will not produce a sufficient number of shirts themselves to cover their domestic demand, they need an assurance that the UK will continue to send shirts their way at a price that makes the trade worthwhile for them.

The exclusive focus on international cooperation in both the economic textbook case for trade and in its analysis in terms of the assurance game is surprising. ${ }^{7}$ It obscures from view the fierce competition between countries that undoubtedly characterises international trade. ${ }^{8}$ One potential explanation for this oversight might be the fact that basic models are usually limited to two countries; as a consequence, there is no third country that could represent a source of competition.

Third, the case for trade is regularly made in terms of 'free' trade. Because trade is beneficial (see claim 1 above), trade liberalisation is also presented as beneficial for the same reasons. The idea of 'free' trade has permeated popular discourse; countries today do not sign trade agreements, they sign 'free' trade agreements. And yet, 'free' trade, when understood as entirely unregulated trade, is a myth. Just like any market interaction, trade requires a whole host of legal background arrangements in order to function. Property rights need to be enforced, contract law needs to be in place, and so on.

Someone might object that no one actually defends 'free' trade as entirely unregulated trade. In response, it is useful to distinguish between marketenabling (and thus trade-enabling) regulation on the one hand and market intervention on the other. Whereas market-enabling regulation is necessary for the proper functioning of economic exchanges and thus for trade, market intervention structures trade in a certain way that aligns with broader social

6 Aaron James, Fairness in Practice (Oxford: Oxford University Press, 2012), p.55ff.

7 I thank an anonymous referee for pushing me to add two caveats here. First, in the limit case of unilateral trade liberalisation, there is no cooperation, but there is no competition either. Second, cooperation between states in the sense discussed here is compatible with competition between firms. In fact, the latter is instrumental in promoting growth and thus creating gains from trade. However, my argument here concerns competition between states not firms.

8 From this perspective, limiting questions about fairness in trade to the distribution of the gains from trade is a mistake. They need to be complemented by questions about access to trading opportunities or, in other words, an account of what constitutes a level-playing field in trade. For a contribution that emphasizes the competitive aspect of trade, see Sylvie Loriaux and Alexia Herwig, 'International Trade, Fairness, and Labour Migration', Moral Philosophy and Politics 1/2 (2014), 289-313. 
objectives. The latter include both allocative and distributive concerns, that is, they can promote both the use of resources in their most efficient use and the distribution of resources in a just or socially desirable manner; for instance, a country might introduce a temporary tariff to protect an infant industry until it can compete on the world market (allocative) or it might impose the tariff in order to protect the wages of workers in its domestic industry (distributive). That being said, drawing a clear line between the various motives behind a market intervention of this kind can be difficult.

Now, while 'free' trade as freedom from market intervention is indeed possible, and thus not a myth, the case that trade of this sort is welfare-enhancing is shaky. One might think that market-enabling regulation will be welfare-enhancing because it will deepen specialisation and thus promote GDP growth whereas market intervention will not be. Unfortunately, things are not that simple. ${ }^{9}$ As already pointed out above, there are situations where more trade will not necessarily promote growth. Moreover, the social welfare function might be sensitive to social objectives other than economic growth; if these objectives require a kind of market intervention that restricts trade, a compromise will have to be found.

\section{The distribution of the gains from trade}

Suppose we grant that trade is beneficial in the sense that it produces gains from specialisation. ${ }^{10}$ Nothing has been said so far about the relative distribution of these gains from trade. Early on in economic theories of trade, it was John Stuart Mill who extended Ricardo's analysis to this question. ${ }^{11}$ In the classic two-country model, what Alfred Marshall would later call the terms of trade of a country are influenced by the demand in a country for the goods produced by the other. ${ }^{12}$ Again using subsequently developed terminology, the country producing the good for which demand is relatively inelastic will have favourable terms of trade. As Blaug states, the economies of scale of large countries can also tilt the terms of trade in their favour. ${ }^{13}$

The contributions to the economic theory of trade provide a descriptive account of the distribution of the gains from trade. The normative question of whether anyone should receive more or fewer of these gains is not raised in economic theory. This question lies at the heart of contemporary philosophical analyses of trade.

9 For a general argument that less market regulation does not imply enhanced well-being, see R.G. Lipsey and Kelvin Lancaster, 'The General Theory of Second Best', Review of Economic Studies 24/1 (1956-57), 11-32.

10 That is, we set aside some of the empirical quibbles about this case discussed under the first point in the previous section.

11 John Stuart Mill, Essays on Some Unsettled Questions of Political Economy, 2nd edition (London: Longmans, Green, Reader, and Dyer, 1874 [1844]).

12 Alfred Marshall, Money, Credit and Commerce (London: Macmillan and Co., 1923), p. 161.

13 Mark Blaug, Economic Theory in Retrospect, 5th edition (Cambridge: Cambridge University Press, 1997), p. 197. 
By way of illustration, consider two of the principles defended by one of the prominent theories of justice in trade, developed by Aaron James. ${ }^{14}$ I should emphasize up front that I do not endorse James' theory in this paper, but I will rather use it to show how normative issues of investor protection intersect with one prominent way of framing questions of justice in trade more generally. The two out of James's total of three principles that are relevant for us here are: ${ }^{15}$

International Relative Gains - 'gains to each trading society, adjusted according to their respective national endowments [...] are to be distributed equally, unless unequal gains flow [...] to poor countries'

Domestic Relative Gains - 'gains to a given trading society are to be distributed equally among its affected members, unless special reasons justify inequality of gain as acceptable to each'

International Relative Gains claims that the gains from trade should not simply be left to fall where they would if determined by the terms of trade of a country. Why? As illustrated by the assurance game that James uses as a background model, the dependence between the trading parties to realise the gains from trade is mutual and of the same degree. My point here is not to defend or criticise James's stance on this question, but to underscore his point that even if we accept that trade will make the economic pie bigger, this leaves entirely open the question of how this pie should be distributed. In other words, even if one accepted Teson's claim ${ }^{16}$ that trade is required by justice because it is mutually beneficial, this leaves open and is entirely compatible with asking the question of how the resulting benefits should be distributed.

Domestic Relative Gains proposes to apply a similar reasoning at the domestic level. Those who contribute to commercial exchanges, and thus to cooperation, with other countries should benefit to the same degree from doing so.

As we shall see in the following section, both of these principles are relevant for the assessment of investor protection clauses.

\section{The domestic distribution of the gains from trade}

Even those who do not accept James's principle of domestic relative gains and its strong equality requirement will acknowledge that the distribution of the gains from trade is relevant to the overall assessment of trade and to the justification of particular trading practices or policies.

Consider one very basic example. Suppose a country has in the past protected its agricultural sector by imposing import tariffs on agricultural goods. Now

14 James (2012).

15 Ibid., pp. 203-204.

16 Teson (2012). 
the country is proposing to repeal these tariffs. Such a move would have two effects. First, more agricultural goods would be imported and global welfare would increase since these goods would now be produced in places that have a comparative advantage in agriculture. Second, the agricultural sector of the country in question would lose out, which might justify a temporary compensation payment to them. ${ }^{17}$

In addition to particular sectors of the economy emerging as winners or losers of trade policy, one particularly salient distributive question is that between labour and capital. This concerns both the distribution between labour and domestic capital (see James' Domestic Relative Gains principle) and between labour and foreign direct investment (see James' International Relative Gains principle). In the cases of investor protection at the heart of this paper, James' international principle requires an equal distribution of the gains from trade between the capital-exporting nation and the capital-importing nation, whereas his domestic principle additionally requires that within the capitalimporting nation, the gains from trade should be shared equally between labour and capital. ${ }^{18}$ It is difficult to isolate the question of the domestic distribution of the gains from trade from the question of the international distribution of the gains from trade. In section 3, I will bracket this distinction for two reasons. First, given the extreme mobility of capital today, the distinction between domestic and foreign capital seems less and less relevant. Second, drawing the distinction would make my argument significantly more complicated without adding substantial insight. ${ }^{19}$

As has been documented and discussed in the literature, ${ }^{20}$ an increasing share of the national product has been going to capital in developed countries since the 1970s. Certain types of provisions of trade agreements can exacerbate this trend.

As already implicit in section 1.1, any trade policy and any trade agreement - even market-enabling regulation - will necessarily have distributive consequences. ${ }^{21}$ These consequences should feed into our all-things-considered

17 The rationale for this compensation is merely to cushion their loss. I am not making a more general claim here about the distributive justice of the world with or without tariff.

18 I thank an anonymous referee for alerting me to the fact that both of James' principles are concerned here.

19 That said, more research is needed on justice in trade under conditions of capital mobility.

20 See for example Anthony Atkinson, 'Factor Shares: The Principal Problem of Political Economy?', Oxford Review of Economic Policy 25/1 (2009), 3-16, p. 9. The question of relative factor shares is also one of the underlying themes of Andrew Glyn's work. See Andrew Glyn, 'Functional Distribution and Inequality', in Brian Nolan, Wiemer Salverda, and Timothy M. Smeeding (eds.), The Oxford Handbook of Economic Inequality, (Oxford, Oxford University Press, 2011) and Andrew Glyn, Capitalism Unleashed - Finance, Globalization, and Welfare (Oxford: Oxford University Press, 2006).

21 Cf. the idea of process redistribution in Peter Dietsch, 'The Market, Competition, and Equality', Politics, Philosophy \& Economics 9/2 (2010), 213-44. 


\section{GROWING THE PIE OR SLICING IT DIFFERENTLY - ON THE NEED \\ TO DISENTANGLE TWO ASPECTS OF TRADE AGREEMENTS}

evaluation of the policies in question. If our theory of economic and social justice tells us that capital is receiving too high a share of the national product, ${ }^{22}$ and if a particular trade policy will likely shift the balance further in the interest of capital, then this is, ceteris paribus, an argument against this trade policy.

\section{Distinguishing aggregate vs. distributive aspects of trade}

According to the WTO website, ${ }^{23} 279$ regional trade agreements were in force as of 1 February 2016. In the case of TTIP, the declared objective was to enhance trade between the EU and the US. Some commentators also saw it as a dry run for trade agreements with large developing countries such as China and India.

Given that average tariffs between the EU and the US are already below 3 per cent for manufactured goods, ${ }^{24}$ the benefits of TTIP were not expected to primarily come from the abolition of tariffs, but from so-called non-tariff measures. $^{25}$ The latter include the harmonisation of product regulation, where current discrepancies make it more cumbersome and more costly for corporations to export in markets with different regulations. Examples in this category range from the benign - indicators of cars for instance tend to be red in the US, while they are yellow in most European countries; to the hotly contested - chicken meat in the US is treated with a chlorine bath, whereas this is not the case in the EU (at least not for chicken).

This paper does not have the ambition to analyse every aspect of TTIP $^{26}$ from a normative perspective. Instead, it focuses on investor protection clauses as a generic issue that arises in the context of any trade negotiation today. Suppose a European-based firm invests in the US, but then the regulatory environment changes - for example, a federal minimum wage of $\$ 15$ is enacted or the laws protecting the environment become stricter. Under the proposed arrangement, the firm would then have the right to sue the US government in front of an international court of arbitration for the losses it occurs as a consequence of the

22 I should emphasize that I do not provide a substantive theory of justice in trade in this paper that would provide the necessary benchmark to make such a statement.

23 See <https://www.wto.org/english/tratop_e/region_e/region_e.htm> (Accessed: 17 November 2017).

24 Gabriel Felbermayr, Mario Larch, Lisandra Flach, Erdal Yalcin and Sebastian Benz, 'Dimensionen und Auswirkungen eines Freihandelsabkommens zwischen der EU und den USA', Studie im Auftrag des Bundesministeriums für Wirtschaft und Technologie, Endbericht, ifo Institut, München (January 2013), p. 39. <https://www.cesifo-group. de/DocDL/ifo_Forschungsberichte_62.pdf> (Accessed: 17 Nov 2017).

25 Werner Raza, Bernhard Tröster, and Rudi von Arnim, 'The Blind Spots of Trade Impact Assessment: Macroeconomic Adjustment Costs and the Social Costs of Regulatory Change', European Journal of Economics and Economic Policies: Intervention 13/1 (2016), 87-102, p. 88.

26 For an excellent introduction to TTIP and what is at stake, see Ferdi De Ville and Gabriel Siles-Brügge, TTIP: The Truth about the Transatlatic Trade and Investment Partnership (Cambridge; Malden, MA: Polity, 2016). For a comprehensive assessment of bilateral investment treaties more generally, cf. Jeswald W. Salacuse and Nicholas P. Sullivan, 'Do BITs Really Work? An Evaluation of Bilateral Investment Treaties and their Grand Bargain', Harvard International Law Journal 46/1 (2005), 67-130. 
change in regulation. ${ }^{27}$

Note two things about this proposed investor protection. First, it fundamentally changes the allocation of risks traditionally associated with investments. If I invest money in a project that subsequently goes belly-up or delivers less of a yield than anticipated, then this is usually considered to be my problem. The investor protection envisaged here takes a certain type of risk, namely that of regulatory change, and transfers it away from the investor and to the state in question. For the state, of course, the risk is not the regulatory change itself, which lies within its democratic powers, but the damages that might be awarded to investors as a result. This risk has to be weighed against the expected benefits of investor protection.

Second, an investor protection regime of this sort would have distributive consequences, too. These manifest themselves through two basic channels. If the investor protection did indeed lead to a higher level of overall investment, this would lead to more employment - call this the employment channel. In any case, however, it favours investors and thus capital interests over workers - call this the relative income channel. The advantages favouring capital under the relative income channel take two principal forms. First, by transferring risks away from corporations, investor protection effectively lowers their costs, thus increasing profits and favouring those holding the residual rights to those profits, i.e. shareholders. Second, investor protection changes the incentives of states to legislate. Plausibly, given the new legal risks they face, they will be more reluctant to introduce legislation that favours labour over capital. The two transmission channels just outlined, the employment channel and the relative income channel, will play a central role in our analysis in the next section.

Can investor protection of this sort be justified and, if so, how? My goal in the next section is to construct a number of ideal-type trade scenarios to illustrate the potential effects of investor protection regulation. In parallel, I will ask which normative positions on trade could potentially justify investor protection in these scenarios. Note one crucial disclaimer: One thing this paper does not attempt to do is to establish which of the ideal-type trade scenarios actually corresponds to the real world. This means that I can only provide a conditional assessment of investor protection rights. To extend this account to an evaluation of TTIP, or of any other potential trade agreement for that matter, more empirical work is needed to link the particular trade agreement in question to one of my scenarios. Besides, this paper abstracts away important

27 One point of contention in the debate is who should appoint judges serving on investor-state dispute settlement (ISDS) courts. Critics fear that corporations might wield too much power over these courts and over the nominations of judges to them, especially if the courts are no longer subject to national jurisdictions. 


\section{GROWING THE PIE OR SLICING IT DIFFERENTLY - ON THE NEED \\ TO DISENTANGLE TWO ASPECTS OF TRADE AGREEMENTS}

variations in the ways in which bilateral investment treaties are designed. ${ }^{28}$ The devil is in the detail, and we should assume that small changes in the design of such treaties, for instance in the institutional configuration of their investorstate dispute settlement procedures, will make an important difference with respect to the three scenarios outlined in the next section.

\section{Trade versus rent-seeking}

As a background to the ideal-type scenarios to be developed in this section, we first need a base scenario of trade. The following table depicts a simplified trade relation between the EU and the US.

\begin{tabular}{|c|c|c|c|c|c|c|c|c|}
\hline & \multicolumn{3}{|c|}{ AUTARKIC PRODUCTION } & \multicolumn{3}{|c|}{ SPECIALISATION \& TRADE } & \multicolumn{2}{|c|}{ GAINS FROM TRADE } \\
\hline & Cars & & Computers & Cars & & Computers & Cars & Computers \\
\hline EU & 10 & $\&$ & 120 & 24 & or & 300 & \multirow{2}{*}{6} & \multirow{2}{*}{30} \\
\hline US & 8 & $\&$ & 100 & 20 & or & 250 & & \\
\hline
\end{tabular}

Given that the opportunity cost of producing one car is lower in the EU compared to the US, it holds a comparative advantage in the production of cars, while the US has a comparative advantage in computers. This underpins the pattern of specialisation under trade. Specialisation entails a rise in productivity, which explains why the production under trade more than doubles compared to autarky. The difference between the quantities produced under trade (in bold) and the sum of the quantities both economic zones would have produced under autarky represents the gains from trade, i.e. $24-(10+8)=6$ cars and $250-(120+100)=30$ computers. The relative price of cars and computers in trade will lie somewhere between the respective opportunity costs of producing the good in which you have a comparative advantage, i.e. between 12 computers per car (opportunity cost of producing a car in Europe) and 1/8 cars per computer (opportunity cost of producing a computer in the US). This gives a relative price somewhere between 12 and 12.5 computers per car. The closer the price is to 12.5, the more favourable the terms of trade will be for Europe; the closer it is to 12 , the better for the US. This will determine how much of the gains from trade (see last two columns of the table) will be appropriated by the EU and US respectively.

However, the question that interests us here is not the division of the gains from trade between countries, but the division of the gains from trade between labour and capital within countries - the domestic distribution of gains from trade discussed in section 1.3 above. Our question, recall, is whether investor

28 See Todd Allee and Clint Peinhardt, 'Evaluating Three Explanations for the Design of Bilateral Investment Treaties', World Politics 66/1 (2014), 47-87. 
protection as envisaged by TTIP will affect both the level of investment and the domestic distribution of the gains from trade between labour and capital and, if so, what the nature of this effect might be.

To answer these questions, let us extend the baseline scenario. Suppose a car costs $\$ 10$ ooo and a computer $\$ 1$ ooo, and suppose also that $60 \%$ of the national product goes to labour, whereas $40 \%$ go to capital (where the latter include the profits of car and computer manufacturers). ${ }^{29}$ This means that under the baseline scenario:

\begin{tabular}{|l|l|l|}
\multicolumn{1}{c|}{$\begin{array}{c}\text { BASELINE } \\
\text { SCENARIO }\end{array}$} & \multicolumn{1}{|c}{ DOMESTIC DIVISION OF THE GAINS FROM TRADE } \\
\hline EU & Labour & Capital \\
US & $\$ 144000^{*}$ & $\$ 96000$ \\
\hline 150000 & $\$ 100000$ \\
\hline "Here is one illustration of how these figures are calculated: & \\
$24 \times \$ 10000=\$ 240000.60 \%$ of $\$ 240000=\$ 144000$. &
\end{tabular}

What would happen if investor protection à la TTIP were introduced? More specifically, what impact would investor protection have through the employment channel as well as through the relative income channel?

Let us set aside two scenarios. First, the scenario where investor protection affects neither employment nor relative income; second, the scenario where investor protection boosts employment but has no effect on relative incomes. The former is unlikely; the second is naïve, because an increase in employment is bound to affect relative prices and thus have distributive effects. This leaves us with three relevant scenarios. The numbers in the various scenarios are merely meant to make the issue at hand more tangible and help us think through the normative issues involved.

1. Same pie, more inequality

\begin{tabular}{|l|l|l}
\multicolumn{2}{r|}{$\begin{array}{c}\text { BASELINE } \\
\text { SCENARIO }\end{array}$} & \multicolumn{2}{c}{ DOMESTIC DIVISION OF THE GAINS FROM TRADE } \\
EU & Labour & Capital \\
US & $\$ 132000$ & $\$ 108000$ \\
\hline 137500 & $\$ 112500$
\end{tabular}

In this scenario, investor protection does not accomplish its declared objective, that is, it does not lead to more investment and thus more employment.

29 According to Glyn (2006), this is a realistic division of how much of the national product goes to the respective factors of production. In recent years, the labour share of the national product has declined. See International Labour Organization and Organisation of Economic Co-operation and Development, with contributions from International Monetary Fund and World Bank Group, 'The Labour Share in G2o Economies', report prepared for the G20 Employment Working Group, Antalya, Turkey, 26-27 February 2015, available at <https://www.oecd.org/g20/ topics/employment-and-social-policy/The-Labour-Share-in-G2O-Economies.pdf> (Accessed: 5 July 2017). 


\section{GROWING THE PIE OR SLICING IT DIFFERENTLY - ON THE NEED \\ TO DISENTANGLE TWO ASPECTS OF TRADE AGREEMENTS}

You might say that this is unlikely given the reduced risk associated with new investments. But as the aftermath of the financial crisis of 2008 shows, favourable investment conditions - in this case, low interest rates - are not enough to convince corporations to make investments. As Keynes highlighted, this requires confidence that there is sufficient demand for their products. ${ }^{30}$ In the absence of this confidence, investor protection might not be an effective tool to boost employment while increasing inequality through the relative income channel all the same. ${ }^{31}$

Another reason why enhancing trade through measures such as investor protection might not actually have the expected positive effects are 'macroeconomic adjustment costs and the social costs of regulatory change'.$^{32}$ Economic models often presume that regulation happens instantly, but nontariff measures in particular often entail significant costs of adjustment. Beyond the question of transitional adjustment costs, one also needs to take into account the legal costs a country is likely to incur if it needs to defend itself in investorstate dispute settlements.

Put differently, investor protection under this scenario might be described as a rent-seeking exercise that allows capital to appropriate a larger share of the pie in a zero-sum game. Such rent-seeking does not deliver any gains of the sort trade between countries is supposed to. If and when this scenario is realistic, this will significantly undermine the case for investor protection. Investment treaties should be evaluated on a case by case basis, but it is worth pointing out that there are studies who put TTIP in this category. For instance, Skovgaard Poulsen et al. in their analysis of the potential impact of an EU-US investment chapter on the UK argue that 'existing evidence suggests that [it] [...] is highly unlikely to encourage investment above and beyond what would otherwise take place.'33 Similarly, Yackee finds no clear evidence for the idea bilateral investment treaties that offer investor protection actually result in higher levels of investment. ${ }^{34}$

30 John Maynard Keynes, The General Theory of Employment, Interest and Money (London: Harcourt, 1964 [1936]). 31 The numbers in the table are based on a $55 \%-45 \%$ division of the national product between labour and capital.

32 Raza et al. (2016), p.87.

33 Lauge N. Skovgaard Poulsen, Jonathan Bonnitcha and Jason Webb Yackee, 'Costs and Benefits of an EU-USA Investment Protection Treaty', report prepared for the Department of Business, Innovation and Skills of the London School of Economics and Political Science, April 2013, p.44.

34 Jason Webb Yackee, 'Bilateral Investment Treaties, Credible Commitment, and the Rule of (International) Law: Do BITs Promote Foreign Direct Investment?', Law \& Society Review 42/4 (2008), 805-31. 
2. More pie for everyone, but larger increases for some

\begin{tabular}{|l|l|l}
\multicolumn{2}{r|}{$\begin{array}{c}\text { BASELINE } \\
\text { SCENARIO }\end{array}$} & \multicolumn{1}{|c}{ DOMESTIC DIVISION OF THE GAINS FROM TRADE } \\
EU & Labour & Capital \\
US & $\$ 150000$ & $\$ 114000$ \\
\hline 156250 & $\$ 118750$
\end{tabular}

Suppose investor protection boosts production by 10\%, 1 additional car and 25 additional computers. However, in the case where investor protection boost profits and thus benefits capitalists and where it discourages governments from adopting labour-friendly policies, only a small share, $25 \%$ say, of the additional national product goes to labour, whereas $75 \%$ goes to capital. Labour gains in absolute terms because the positive impact of investor-protection through the employment channel outweighs the negative impact through the relative income channel.

3. Larger pie, but only some benefit whereas others lose out

\begin{tabular}{|l|l|l}
\multicolumn{2}{r|}{$\begin{array}{c}\text { BASELINE } \\
\text { SCENARIO }\end{array}$} & \multicolumn{2}{c}{ DOMESTIC DIVISION OF THE GAINS FROM TRADE } \\
EU & Labour & Capital \\
US & $\$ 132000$ & $\$ 132000$ \\
\hline 137500 & $\$ 137500$
\end{tabular}

Here, we also see a $10 \%$ boost in production, but contrary to scenario 2, all of it and more go to capital. In other words, in this scenario investor protection has a strong impact through the relative incomes channel and actually worsens the position of workers, whose income share drops by $5 \%$ of national income. Capital, by contrast, receives the entire $10 \%$ boost in production plus the $5 \%$ income share from labour.

Even if this scenario entails a boost to employment, the inegalitarian impact of investor protection is problematic. It might warrant measures by governments to compensate the losers of this trade arrangement. It might even warrant questioning the justification of investor protection altogether if we consider that the trade-off between inequality and employment is not favourable. However, given the political focus on employment and GDP today, these questions are likely to be swept under the carpet.

I suspect the real world lies somewhere between scenarios 2 and 3, but this is purely speculative. As I said, empirical work is needed to establish what the likely impact of investor protection à la TTIP would be. However, it seems to me that it would be irresponsible to adopt investor protection without asking the above questions and making a serious effort to determine which of the scenarios TTIP corresponds to. 


\section{GROWING THE PIE OR SLICING IT DIFFERENTLY - ON THE NEED \\ TO DISENTANGLE TWO ASPECTS OF TRADE AGREEMENTS}

\section{Conclusion}

When trade agreements are discussed today, the implicit assumption is that more trade benefits everyone. This is not always the case. Especially in cases where most gains from trade have already been exploited, such as the lowtariff environment of the EU-US trade, additional trade measures might have significant distributive effects. Investor protection is one example in this category.

This paper has urged to take seriously the distinction between two questions, namely the generation of gains from trade on the one hand and the distribution of these gains domestically on the other. In particular, I have looked at the distribution of gains from trade between labour and capital.

Trade impact assessments should take this distinction seriously. The different scenarios of the impact of investor protection presented in section 3 show that distributive concerns have the potential to change our assessment of particular trade measures. They suggest that the envisaged investor protection arrangements might at least in part be a rent-seeking exercise on the part of investors rather than a source of genuine gains from trade. Even when investor protection does in fact stimulate employment and growth, this is not a sufficient reason to accept it, because this growth might come at the expense of some domestic constituencies. As I have emphasized, more empirical work is needed to corroborate claims of this kind in the case of TTIP or other trade treaties. ${ }^{35}$

\section{Peter Dietsch \\ Full Professor \\ Département de Philosophie, Université de \\ Montréal \\ et Centre de Recherche en Éthique \\ Email:peter.dietsch@umontreal.ca}

\section{the global justicenetwork}

35 A previous version of this paper was presented at the workshop Normative Reflections on the Transatlantic Trade and Investment Partnership (TTIP) : Fair Trade, Justice, Democracy, and State Sovereignty organised by Julian Culp, Tamara Jugov, and Miriam Ronzoni at the European University Institute (EUI) in Florence in June 2016. I would like to thank the organisers, as well as my commentator Christine Straehle and the workshop participants for their helpful comments on the paper. Thank you also to the anonymous referees who provided constructive feedback on the paper. This research has been supported by funding from the Social Sciences and Humanities Research Council (SSHRC) of Canada. The paper has also been published as a working paper at the European University Institute (EUI), see <http://cadmus.eui.eu/handle/1814/47285>. 